\title{
Penggunaan media sosial dan peran orang tua terhadap kejadian pernikahan dini
}

\author{
Asnuddin*, Asrini Mattrah
}

Program Studi IImu Keperawatan STIKES Muhammadiyah Sidrap, Sidenreng Rappang Sulawesi Selatan.

*Email: asnuddin20@gmail.com

\begin{abstract}
Social media use: The role of parents' perceptions about social media impact in early marriage
\end{abstract}

Background: Early marriage is a marriage that is conducted at adolescence, the factors causing early marriage are socio-cultural factors, economic pressure, level of education, difficulty in getting a job, social media, religion and views and beliefs

Purpose: To find out the influence of social media and the role of parents on the incidence of early marriage

Method: A quantitative research using descriptive analytical research method with cross sectional study design with variable use of social media with the criteria for the results "active and inactive". For the variable of the role of parents with 2 outcome criteria, namely "influential and not influential". And for the variable incidence of early marriage, there are 2 criteria, namely age 14-16 years and age 17-19 years, the questionnaire used has been through the validity of previous researchers. Then the results of the data obtained were analyzed in the SPSS program using the Chi Square test

Results: From the Chi Square test results for social media variables obtained $p$ value $=0.001$, then the value of $p$ $=0.001<0.05(\mathrm{a})$ while the role of parents variable Chi Square test results obtained $p$ value $=0.022$, therefore the value of $p=0.022<0.05(a)$.

Conclusion: Based on the results of the study it can be concluded that, there is a significant influence between the use of social media and the role of parents in the event of early marriage

\section{Keywords: Social media; Parents, Early marriage}

Pendahuluan: Pernikahan usia dini adalah perkawinan yang dilakukan pada usia remaja, faktor penyebab pernikahan usia dini adalah faktor sosial budaya, desakan ekonomi, tingkat pendidikan, sulit mendapat pekerjaan, media sosial, agama serta pandangan dan kepercayaan.

Tujuan: Untuk mengetahui pengaruh media sosial dan peran orang tua terhadap kejadian pernikahan dini di Kecamatan Marioriawa Kabupaten Soppeng

Metode: Penelitian kuantitatif dengan menggunakan metode penelitian deskriptif analitik dengan rancangan cross sectional study dengan variabel penggunaan media sosial dengan kriteria hasil "aktif dan tidak aktif". Untuk variabel peran orang tua dengan 2 kriteria hasil yaitu "berpengaruh dan tidak berpengaruh". Dan untuk variabel kejadian pernikahan dini ada 2 kriteria yaitu umur 14-16 tahun dan umur 17-19 tahun, kuesioner yang di gunakan sudah melalui uji validitas peneliti sebelumnya. Kemudian hasil data yang di dapatkan dianalisis di program SPSS dengan menggunakan uji Chi Square

Hasil: Dari hasil uji Chi Square untuk variabel media sosial didapatkan nilai $p=0,001$, maka nilai $p=0.001<0.05$ (a) sedangkan variabel peran orang tua hasil uji Chi Square didapatkan nilai $p=0,022$, oleh karena itu nilai $\mathrm{p}=0.022<0.05$ (a).

Simpulan: Berdasarkan hasil penelitian dapat di simpulkan bahwa, Ada pengaruh yang signifikan antara penggunaan media sosial dan peran orang tua terhadap kejadian pernikahan dini

\section{Kata Kunci: Media sosial; Orang tua; Pernikahan dini}

\section{PENDAHULUAN}

Masa remaja adalah periode kehidupan manusia yang sangat strategis, penting dan berdampak luas bagi perkembangan berikutnya. Pada remaja awal, pertumbuhan fisiknya sangat pesat tapi tidak proporsioanal, misalnya pada hidung, tangan dan kaki. Pada remaja akhir, proporsi tubuh mencapai ukuran tubuh orang dewasa dalam semua bagianya (Hadiono, 2018)

Peran orang tua sangat menentukan remaja untuk menjalani pernikahan di usia muda juga mengungkapkan bahwa orang tua yang memiliki 
Penggunaan media sosial dan peran orang tua terhadap kejadian pernikahan dini

keterbatasan pemahaman khususnya tentang kesehatan reproduksi, hak anak maka kecenderungan yang terjadi adalah menikahkan anaknya. Orang tua memiliki peran yang besar terhadap kejadian pernikahan dini. Selain itu orang tua juga memiliki peran yang besar dalam penundaan usia perkawinan anak (Desiyanti, 2015).

Besarnya peran orang tua ditinjau dari segi perspektif komunikasi keluarga yang mana peranperan tersebut merupakan salah satu penentu keputusan seorang remaja untuk menikah pada usia muda. Keluarga yang tidak memiliki hubungan yang harmonis akan berdampak pada perilaku seks bebas anak dan dapat berujung pada pernikahan usia dini (Desiyanti, 2015).

Menurut Arimurti \& Nurmala, (2017) Pernikahan usia dini masih banyak terjadi di berbagai daerah di Indonesia. Banyak faktor yang dapat menyebabkan terjadinya pernikahan usia dini, faktor penyebab pernikahan usia dini adalah faktor sosial budaya, desakan ekonomi, tingkat pendidikan, sulit mendapat pekerjaan, media sosial, agama serta pandangan dan kepercayaan (Pohan, 2017).

Perubahan teknologi komunikasi ini dapat mempunyai dampak positif dan negatif bagi seorang remaja. Apalagi masa remaja adalah masa transisi yang sedang mencari jati diri. Tanpa adanya bimbingan, dan pengawasan dari keluarga ataupun orang-orang terdekat, teknologi komunikasi dapat dimanfaatkan untuk melakukan perbuatan yang negatif, yang melanggar nilai dan norma yang berlaku dalam masyarakat (Astuti, 2018).

Teknologi Informasi di era globalisasi sangat berkembang pesat di dalam kehidupan masyarakat. Penggunaan fasilitas komunikasi yang semakin canggih memberikan peluang bagi setiap individu untuk mengakses informasi sesuai keinginan serta dapat berkomunikasi dengan mudah tanpa memikirkan waktu (Juwita, Budimansyah, \& Nurbayani, 2015).

Dengan pesatnya perkembangan new media, telah memberikan dampak terhadap situs-situs komunikasi, dari sekedar email dan chatting, menjadi media sosial atau jejaring sosial seperti Facebook, Twitter, Instagram, Path, Snapchat (Mahendra, 2017).

Media sosial telah menjadi sebuah sarana umum yang dipergunakan dalam kehidupan individu sehari-hari dan era baru dalam proses belajar mengajar (Kalasi, 2014).

Tidak dapat dipungkiri bahwa media sosial mempunyai pengaruh yang besar dalam kehidupan seseorang. Seseorang yang awalnya kecil bisa menjadi besar dengan media sosial, atau sebaliknya. Bagi masyarakat khususnya kalangan remaja, media sosial sudah menjadi candu yang membuat penggunanya tiada hari tanpa membuka media sosial (Putri, Nurwati, \& Budiarti, 2016).

Daya tarik media sosial inilah yang kemudian memegang peranan penting dalam membangun kemampuan berkomunikasi seseorang. Remaja saat ini begitu peka dengan perubahan yang terjadi dalam teknologi sosial. Pemilihan dan akses remaja terhadap media sosial mungkin didasarkan pada berbagai tujuan, salah satunya adalah kebutuhan mencari informasi, mendokumentasikan setiap peristiwa yang terjadi, dan kebutuhan bersosialisasi (Gita, et all., 2017).

Pria maupun wanita dalam mempersiapkan perkawinan perlu mempertimbangkan usia yang tepat. Idealnya sebuah perkawinan dilakukan dalam kondisi siap secara fisik, mental dan ekonomi. Data global menyebutkan bahwa lebih dari 700 juta perempuan yang hidup saat ini menikah sebelum mencapai usia dewasa, yaitu 18 tahun dan sekitar 250 juta anak menikah sebelum usia 15 tahun. Di Indonesia sendiri, angka prevalensi perkawinan usia anak sebesar $17 \%$ (Taufik, Sutiani, \& Hernawan, 2018).

Dampak Sosial terjadinya pernikahan usia dini yaitu keterbatasan ruang lingkup untuk bergaul dengan teman-teman seumuran, sehingga remaja kurang dapat membicarakan masalah yang dihadapinya (Arimurti, \& Nurmala, 2017).

\section{METODE PENELITIAN}

Penelitian kuantitatif dengan menggunakan metode penelitian deskriptif analitik dengan rancangan cross sectional study dengan menggunakan kuesioner dimana untuk variabel penggunaan media sosial jumlah pertayaan 14 dengan kategori ya dan tidak dengan menggunakan 2 kriteria hasil yaitu aktif jika skor 07 dan tidak aktif 8-14 dimana skor terendah 0 dan skor tertinggi 14. Untuk variabel peran orang tua masing-masing menggunakan 12 pertanyaan kategori ya dan tidak dengan 2 kriteria hasil yaitu berpengaruh jika skor $0-6$ dan tidak berpengaruh jika skor 7-12 dimana skor terendah 0 dan skor

\section{Asnuddin*, Asrini Mattrah}

Program Studi llmu Keperawatan STIKES Muhammadiyah Sidrap, Sidenreng Rappang Sulawesi Selatan.

*Email: asnuddin20@gmail.com 
tertinggi 12. Dan untuk variabel kejadian pernikahan dini ada 2 kriteria yaitu umur 14-16 tahun dan umur 17-19 tahun, kuesioner yang di gunakan sudah melalui uji validitas peneliti sebelumnya. Kemudian hasil data yang di dapatkan dianalisis di program SPSS dengan menggunakan uji Chi Square.

\section{HASIL}

Tabel 1. Karakteristik Demografi Responden $\mathrm{N}=60$

\begin{tabular}{lllll}
\hline Demografi & & $\mathbf{n}$ & $\%$ & $\mathbf{M} \mathbf{S} \mathbf{D}$ \\
& & & & \\
\hline Usia (Tahun)(Rentang: 14-19) & & 46 & & $16.00 \pm 1.491$ \\
Jenis Kelamin & Laki-laki & 12 & 26.1 & \\
& Perempuan & 34 & 73.9 & \\
Pendidikan & SD & 10 & 21.7 \\
& SMP & 23 & 50.0 \\
& SMA & 13 & 28.3 \\
Pekerjaan & Bekerja & 34 & 73.9 \\
& Tidak bekerja & 12 & 26.1 \\
Media Sosial & Aktif & & \\
& Tidak Aktif & 31 & 67.4 \\
Peran Orang Tua & Berpengaruh & 15 & 32.6 \\
& Tidak Berpengaruh & 28 & 60.9 & \\
Usia Menikah & 14-16 Tahun & 18 & 39.1 & \\
& 17-19 Tahun & 28 & 60.9
\end{tabular}

Berdasarkan tabel 1. diketahui responden sebanyak 46 orang berusia antara 14 tahun sampai 19 tahun dengan mean sebesar 16.00 dan standar deviasi 1.491. Responden berjenis kelamin laki-laki sebanyak 12 orang $(26.1 \%)$ dan perempuan sebanyak 34 orang $(73.9 \%)$. Pendidikan responden yang terbanyak adalah SMP $(50.0 \%)$, dan didominasi oleh responden yang Bekerja (73.9\%). Responden yang menikah di usia dini didapatkan responden yang aktif menggunakan media sosial sebanyak 31 orang $(67.4 \%)$, dan yang tidak aktif menggunakan media sosial sebanyak 15 orang (32.6\%). Untuk variabel peran orang tua diketahui bahwa dari 46 responden yang menikah di usia dini didapatkan responden yang menikah karena pengaruh orang tua sebanyak 28 orang $(60.9 \%)$, dan yang tidak berpengaruh sebanyak 18 orang (39.1\%). Selanjutnya variabel pernikahan dini dapat diketahui bahwa dari 46 responden yang menikah di usia dini didapatkan umur 14-16 tahun sebanyak 28 orang $(60.9 \%)$, dan umur $17-19$ tahun sebanyak 18 orang $(39,1 \%)$. 
Penggunaan media sosial dan peran orang tua terhadap kejadian pernikahan dini

Tabel 2. Hasil Analisis Pengaruh Media Sosial dan Peran Orang Tua Terhadap Kejadian Pernikahan Dini

\begin{tabular}{|c|c|c|c|c|c|c|c|c|}
\hline \multirow[t]{3}{*}{ Variabel } & \multicolumn{4}{|c|}{ Usia pada saat menikah } & \multirow{2}{*}{\multicolumn{2}{|c|}{ Total }} & \multirow{3}{*}{$p$-value } & \multirow{3}{*}{$\begin{array}{c}\text { OR } \\
(95 \% \mathrm{Cl})\end{array}$} \\
\hline & \multicolumn{2}{|c|}{ 14-16 } & \multicolumn{2}{|c|}{$17-19$} & & & & \\
\hline & $\mathrm{n}$ & $\%$ & $\mathrm{n}$ & $\%$ & $\mathbf{N}$ & $\%$ & & \\
\hline \multicolumn{9}{|l|}{ Media Sosial } \\
\hline Aktif & 24 & 52.2 & 7 & 15.2 & 31 & 67.4 & \multirow{2}{*}{0,001} & 9.429 \\
\hline Tidak Aktif & 4 & 8.7 & 11 & 23.9 & 15 & 32.6 & & $(2.277-39.035)$ \\
\hline \multicolumn{9}{|l|}{ Peran Orang Tua } \\
\hline Berpengaruh & 14 & 30.4 & 15 & 32.7 & 29 & 63.0 & \multirow{2}{*}{0.022} & 0.200 \\
\hline Tidak Berpengaruh & 14 & 30.4 & 3 & 6.5 & 17 & 37.0 & & $(0.047-0.848)$ \\
\hline
\end{tabular}

Dari tabel 2. diketahui bahwa dari 46 responden terdapat 24 orang yang aktif di media sosial dan menikah pada usia $14-16$ tahun $(52.2 \%)$ sedangkan yang aktif di media sosial yang menikah pada usia 17-19 tahun sebanyak 7 orang $(15.2 \%)$, adapun yang tidak aktif menggunakan media sosial sebanyak 4 orang yang menikah di umur $14-16$ tahun $(8.7 \%)$ dan yang tidak aktif menggunakan media sosial yang menikah pada usia 17-19 tahun sebanyak 11 orang (23.9\%). Dari hasil uji Chi Square didapatkan nilai $p=0,001$, oleh karena itu nilai $p=0.001<0.05(a)$, maka dapat disimpulkan bahwa Ho ditolak dan Ha diterima, yang artinya ada pengaruh media sosial terhadap kejadian pernikahan dini.

Dari variabel Peran Orang Tua dapat diketahui bahwa dari 46 responden terdapat 14 orang yang kategori berpengaruh dan menikah pada usia 1416 tahun (30.4\%) sedangkan yang kategori berpengaruh yang menikah pada usia 17-19 tahun sebanyak 15 orang $(32.7 \%)$, adapun kategori yang tidak berpengaruh sebanyak 14 orang yang menikah di umur 14-16 tahun (30.4\%) dan kategori yang tidak berpengaruh yang menikah pada usia 17-19 tahun sebanyak 3 orang (6.5\%). Dari hasil uji Chi Square didapatkan nilai $p=0,022$, oleh karena itu nilai $p=0.022<0.05(a)$, maka dapat disimpulkan bahwa Ho ditolak dan Ha diterima, yang artinya ada pengaruh peran orang tua terhadap kejadian pernikahan dini.

\section{PEMBAHASAN}

\section{Media sosial}

Dengan adanya perkembangan teknologi informasi media sosial yang semakin pesat ini, secara perlahan membuat penggunanya semakin ketergantungan untuk menggunakan media sosial.
Kenyataan ini membawa dampak positif dan dampak negatif bagi pengguna (end user). Penggunaan media sosial membawa begitu banyak kemudahan bagi penggunanya. Dengan segala fasilitas yang disediakan oleh media sosial. Namun dibalik kemudahan tersebut kehadiran media sosial juga membawa sisi buruk bagi perilaku penggunannya. Dampak yang paling nyata dan merusak adalah dengan media sosial penggunanya dapat langgsung mengakses kontenkonten asusila yang tak bermoral yang dengan mudah dapat diakses dengan melalui internet (Tegal, 2017).

Masyarakat modern saat ini hampir tidak mungkin tidak terkena paparan media. Disadari atau tidak, media dengan segala kontennya hadir menjadi bagian hidup manusia. Seiring dengan perkembangan jaman, kehadiran media makin beragam dan berkembang (Watie, 2016).

Muncul dan berkembangnya internet membawa cara komunikasi baru di masyarakat. Media sosial hadir dan merubah paradigma berkomunikasi di masyarakat saat ini. Komunikasi tak terbatas jarak, waktu, ruang. Bisa terjadi dimana saja, kapan saja, tanpa harus tatap muka. Bahkan media sosial mampu meniadakan status sosial, yang sering kali sebagai penghambat komunikasi. Dengan hadirnya Twitter, Facebook, Google+ dan sejenisnya, orang-orang tanpa harus bertemu, bisa saling berinteraksi (Watie, 2016)

Telah banyak kita lihat berita-berita dimedia massa yang memuat tentang dampakyang ditimbulkan dari media sosial, muladari berita kesuksesan yang didapatkan darmemanfaatkan media sosial sampai beritatentang penculikan, prostitusi dll sebagainya, semua itu hanyalah sebagian kecil saja, dampak-dampak tersebut 
Penggunaan media sosial dan peran orang tua terhadap kejadian pernikahan dini

telah memberi semacam sugesti terhadap masyarakat untuk bagaimana lebih bijak dalam memanfaatkan media social tersebut terutama para remaja millennial (Ainiyah, 2018)

Berdasarkan hasil penelitian yang dilakukan di wilayah kerja Kantor Urusan Agama Kecamatan Marioriawa Kabupaten Soppeng bahwa dari 46 responden terdapat 24 orang yang aktif di media sosial dan menikah pada usia 14-16 tahun dengan persentase (52.2\%) sedangkan yang aktif di media sosial yang menikah pada usia 17-19 tahun sebanyak 7 orang dengan persentase (15.2\%), adapun yang tidak aktif menggunakan media sosial sebanyak 4 orang yang menikah di umur 14-16 tahun dengan persentase $(8,7 \%)$ dan yang tidak aktif menggunakan media sosial yang menikah pada usia 17-19 tahun sebanyak 11 orang dengan persentase $(23.9 \%)$. Ini menunjukkan bahwa responden yang aktif menggunakan media sosial memiliki resiko lebih besar untuk melakukan pernikahan dini dibandingkan dengan responden yang tidak aktif menggunakan media sosial.

Penelitian ini sejalan dengan penelitian yang dilakukan oleh Sumardi Rahardjo dan Riyanti Imron pada tahun 2013. Hasil yang diperoleh dari penelitian yang ia lakukan yaitu terdapat hubungan yang signifikan antara media dengan pernikahan dini, $\mathrm{P}$ value $=0,000$ dan $\mathrm{OR}=5,53(95 \% \mathrm{Cl}$ : $3,089,95)$, dengan demikian dapat dikatakan bahwa secara statistik responden yang menggunakan media untuk melihat hal-hal negatif memiliki risiko melakukan pernikahan dini 5,53 kali lebih besar dibandingkan dengan responden yang menggu-nakan media untuk melihat hal-hal positif (Febriawati, Wati, \& Arlina, 2020).

Menurut asumsi peneliti media sosial sangat berkembang pesat di masyarakat utamanya dikalangan remaja, ini mengakibatkan seseorang lebih mudah berkomunikasi dan mencari teman melalui media sosial, dikalangan remaja media sosial sangat berperan penting dalam kehidupannya, sehingga hal ini dapat menyebabkan masa depannya akan terganggu apabila tidak cermat dalam menggunakan media sosial, remaja yang aktif menggunakan media sosial akan mempengaruhi kehidupannya sendiri seperti menikah di usia dini dengan pasangan yang di kenal melalui media sosial.

\section{Peran orang tua}

Pola asuh orang tua mempunyai peranan yang sangat penting dalam kehidupan anak. Melalui orang tua, anak beradaptasi dengan lingkungannya dan mengenal dunia sekitarnya serta pola pergaulan hidup yang berlaku di lingkungannya. Ini disebabkan oleh orang tua merupakan dasar pertama bagi pembentukan pribadi anak. Orang tua memegang peranan utama dan pertama bagi pendidikan anak. Mengasuh, membesarkan dan mendidik anak merupakan tugas mulia yang tidak lepas dari berbagai halangan dan tantangan. (Purwaningsih, \& Setyaningsih, 2015).

Berdasarkan hasil penelitian yang di wilayah kerja Kantor Urusan Agama Kecamatan Marioriawa Kabupaten Soppeng di dapatkan hasil bahwa dari 46 responden terdapat 14 orang yang kategori berpengaruh dan menikah pada usia 1416 tahun dengan persentase $(30.4 \%)$ sedangkan yang kategori berpengaruh yang menikah pada usia 17-19 tahun sebanyak 15 orang dengan persentase $(62.0 \%)$, adapun kategori yang tidak berpengaruh sebanyak 14 orang yang menikah di umur 14-16 tahun dengan persentase (30.4\%) dan kategori yang tidak berpengaruh yang menikah pada usia 17-19 tahun sebanyak 3 orang dengan persentase (37.0\%). Ini menunjukkan bahwa orang tua memiliki pengaruh terhadap kejadian pernikahan dini pada anaknya. Jadi peneliti berkesimpulan bahwa peran orang tua memiliki pengaruh terhadap kejadian pernikahan dini di wilayah kerja Kantor Urusan Agama Kecamatan Marioriawa Kabupaten Soppeng.

Penelitian ini sejalan dengan penelitian yang dilakukan oleh Pramana, I Nyoman Adi, Warjiman, Permana dan Luckyta Ibna pada tahun 2017 yang menunjukkan bahwa peran orang tua memiliki pengaruh terhadap kejadian pernikahan dini hal ini dibuktikan dengan hasil analisis Chi-Square Test hasil X2 hitung lebih besar dibandingkan dengan X2 tabel (11.471 > 3.841) dan nilai tingkat signifikan (asymp.sig.2 sided) lebih kecil di bandingkan nilai a $(0.001<0.05)$ (Pramana, Warjiman, \& Permana, 2018).

Penelitian yang tidak sejalan oleh Pohan (2017) Berdasarkan hasil uji Chi Squareterlihat bahwa tidak ada hubungan antara peran orang tua dengan pernikahan usiadini pada remaja putri dengan nilai $p=0,27$ yang berarti lebih besar dari $=$ 0,05 , maka $\mathrm{HO}$ diterima.

\section{Asnuddin*, Asrini Mattrah}

Program Studi llmu Keperawatan STIKES Muhammadiyah Sidrap, Sidenreng Rappang Sulawesi Selatan.

*Email: asnuddin20@gmail.com 
Penggunaan media sosial dan peran orang tua terhadap kejadian pernikahan dini

Penelitian ini tidak sejalan dengan Hasil penelitian Farid (2017) terkait Hasil analisis cluster yang dilakukan di Kabupaten Kediri, diketahui bahwa variabel pendidikan orang tua tidak berpengaruh signifikan terhadap faktor - faktor yang mempengaruhi perkawinan di bawah umur di Kabupaten Kediri. Variabel pendidikan orang tua mempunyai nilai $F=1,892$ dengan $p=$ sig. $=0,173>$ 0,05 .

Remaja yang orang tuanya berperan dalam mengambil keputusan mempunyai resiko 2,121 kali menikah pada usia dini dibanding remaja putri yang orang tuanya tidak berperan dalam mengambil keputusan (Muntamah, Latifiani, \& Arifin, 2019).

Penelitian ini juga sejalan dengan penelitian yang dilakukan oleh Irne W. Desiyanti pada tahun 2015 yang menunjukkan bahwa peran orang tua memilki pengaruh terhadap kejadian pernikahan dini hal ini dibuktikan dengan hasil analisis uji Chi Square didapatkan hasil nilai $\rho=0,000$. Hal ini menunujukkan bahwa $\rho<a$, sehingga terdapat hubungan antara peran orang tua sebagai komponen dalam sistem komunikasi dengan kejadian pernikahan dini pada anaknya (Desiyanti, 2015).

Menurut Wulanuari, et all., (2017) Para orang tua agar dapat menambah pengetahuanmengenai faktor yang berhubungan dengan terjadinya pernikahan dini sehingga dengan bantuan tenaga kesehatan, para orang tua dapat lebih menjaga anakanaknya dan orang tua dapat lebih mempertimbangkan dalam keputusan menikahkan anaknya. Orang tua juga harus mengutamakan pendidikan daripada menikahkan anak, karena dengan pendidikan yang baik maka anak akan mendapatkan pekerjaan yang baik sebagai bekal pada saat menikah.

Menurut asumsi peneliti dari beberapa penelitian yang ada pengaruh antara media sosial dan peran orang tua terhadap kejadian pernikahan dini, hal ini dilihat dari masih adanya kepercayaan sebagian masyarakat umumnya pada orang tua masih meyakini bahwa mengawinkan anak pada usia dini dianggap sebuah kebanggaan tersendiri bagi keluarga, orang tua lebih mengharapkan anaknya untuk menikah di usia dini dibandingkan dengan menyekolahkan anaknya dan remaja yang menikah di usia dini di Kecamatan Marioriawa Kabupaten Soppeng sesuai hasil penelitian yang dilakukan bahwa mereka menikah di usia dini karena dorongan dari orang tua.

\section{SIMPULAN}

Berdasarkan hasil penelitian dapat di simpulkan bahwa, Ada pengaruh yang signifikan antara penggunaan media sosial dan peran orang tua terhadap kejadian pernikahan dini di wilayah kerja Kantor Urusan Agama Kecamatan Marioriawa Kabupaten Soppeng .

\section{SARAN}

Diharapkan bagi remaja yang aktif menggunakan media sosial dapat menghindari halhal yang dapat mengakibatkan terjadinya pernikahan dini. Bagi orang tua seharusnya lebih mementingkan pendidikan untuk anaknya dan lebih mengawasi pergaulan baik di dalam sekolah maupun diluar sekolah sehingga tidak terjadi sesuatu yang berakibat fatal yang akhirnya dapat memunculkan terjadinya pernikahan dini. Dari hasil penelitian ini diharapkan pihak KUA Kecamatan Marioriawa Kabupaten Soppeng melakukan upaya penanggulangan pernikahan dini yang dilakukan secara terprogram (berkala). Diharapkan peneliti selanjutnya dapat melakukan penelitian dengan menambah variabel dan penelitian kearah proses impelementasi untuk mengembangkan penelitian ini.

\section{DAFTAR PUSTAKA}

Ainiyah, N. (2018). Remaja Millenial dan Media Sosial: Media Sosial Sebagai Media Informasi Pendidikan Bagi Remaja Millenial. Jurnal Pendidikan Islam Indonesia, 2(2), 221-236.

Arimurti, I., \& Nurmala, I. (2017). Analisis Pengetahuan Perempuan Terhadap Perilaku Melakukan Pernikahan Usia Dini Di Kecamatan Wonosari Kabupaten Bondowoso. The Indonesian Journal of Public Health, 12(2), 249262.

Astuti, A. P., \& Rps, A. N. (2018). Teknologi Komunikasi dan Perilaku Remaja. Jurnal Analisa Sosiologi, 3(1). 
Desiyanti, I. W. (2015). Faktor-faktor yang berhubungan terhadap pernikahan dini pada pasangan usia subur di Kecamatan Mapanget Kota Manado. Jikmu, 5(3).

Farid. Z. M. (2017). Analisis berbasis cluster tentang faktor-faktor yang mempengaruhi perkawinan di bawah umur di Kabupaten Kediri. Swara Bhumi, 5(IV).

Febriawati, H., Wati, N., \& Arlina, S. (2020). FaktorFaktor Yang Berhubungan Dengan Pernikahan Usia Dini Di Kecamatan Semidang Alas Maras Kabupaten Seluma. Avicenna: Jurnal IImiah, 15(1), 43-53.

Gita. A., \& Dwi, S. W. E. (2017). Hubungan Penggunaan Media Sosial dengan Tingkat Kepekaan Sosial di Usia Remaja. Jurnal The Messenger, 9(1), 65-69.

Hadiono, A. F. (2018). Pernikahan Dini dalam Perspektif Psikologi Komunikasi. Jurnal Darussalam: Jurnal Pendidikan, Komunikasi dan Pemikiran Hukum Islam, 9(2), 385-397.

Juwita, E. P., Budimansyah, D., \& Nurbayani, S. (2015). Peran media sosial terhadap gaya hidup siswa. SOSIETAS, 5(1).

Kalasi, R. (2014). Dunia internet di kalangan remaja pada perkembangan pengetahuan oleh media internet. Jakarta: ECG.

Mahendra, B. (2017). Eksistensi Sosial Remaja dalam Instagram (Sebuah Perspektif Komunikasi). Jurnal Visi Komunikasi, 16(1), $151-160$.

Muntamah, A. L., Latifiani, D., \& Arifin, R. (2019). Pernikahan dini di Indonesia: Faktor dan peran pemerintah (Perspektif penegakan dan perlindungan hukum bagi anak). Widya Yuridika, 2(1), 1-12.
Pohan, N. H. (2017). Faktor-Faktor yang Berhubungan Dengan Pernikahan Usia Dini terhadap Remaja Putri. Jurnal Endurance, 2(3), 424-435.

Pramana, I. N. A., Warjiman, W., \& Permana, L. I. (2018). Faktor-Faktor Yang Mempengaruhi Pernikahan Usia Dini Pada Remaja Wanita. Jurnal Keperawatan Suaka Insan (JKSI), 3(2), 1-14.

Purwaningsih, E., \& Setyaningsih, R. T. (2015). Hubungan Pola Asuh Orang Tua Dengan Kejadian Pernikahan Usia Dini Di Desa Jambu Kidul, Ceper, Klaten. INVOLUSI Jurnal IImu Kebidanan, 4(7).

Putri, W. S. R., Nurwati, N., \& Budiarti, M. (2016). Pengaruh media sosial terhadap perilaku remaja. Prosiding Penelitian dan Pengabdian kepada Masyarakat, 3(1).

Taufik, M., Sutiani, H., \& Hernawan, A. D. (2018). Pengetahuan, Peran Orang Tua dan Persepsi Remaja terhadap Preferensi Usia Ideal Menikah. Jurnal Vokasi Kesehatan, 4(2), 63-69.

Tegal, H. F. A. B. (2017). Perilaku penggunaan media sosial pada kalangan remaja. Indonesian Journal on Software Engineering (IJSE), 3(2).

Watie, E. D. S. (2016). Komunikasi dan media sosial (communications and social media). Jurnal The Messenger, 3(2), 69-74.

Wulanuari, K. A., Anggraini, A. N., \& Suparman, S. (2017). Faktor-Faktor yang Berhubungan dengan Pernikahan Dini pada Wanita. Jurnal Ners dan Kebidanan Indonesia, 5(1), 68-75. 